\title{
OCCURRENCE OF INSECT PESTS IN FRUITS OF Caryocar brasiliense (CARYOCARACEAE) IN THE NORTH OF MINAS GERAIS ${ }^{1}$
}

\author{
RENAN ALVES SANTOS 2 , VINÍCIUS ORLANDI BARBOSA LIMA³ ${ }^{3}$ TATIANNE GIZELLE MARQUES SILVA*
}

\begin{abstract}
Caryocar brasiliense Camb. is a typical species from the Cerrado that represents a relevant income for the population where the fruit is produced. The ocorrence of insect pests provokes damage in the fruit and making its commercialization unfeasible. Then, this study aimed to identify the pest insect the fruit and the pit; to compare the morphological features of the fruit and pit and the damage caused by insects among mother plants and their origins and correlate the fruit and pit morphological features with the damage caused by the insects. Three different origins were evaluated, 12 mother plants by origin and ten fruit by mother plant. All the fruit were opened, checked for the insect damage and the fruit and pit morphological variables were determined. The insects that caused damage to the pequi embryo were identified as Carmenta sp. (Lepidoptera: Sesiidae) and Amblycerus sp (Coleoptera: Chrysomelidae). The probability analysis showed significant effect on the mother plants and origins for the percentage of fruit and pit attacked where the location of Laje Velha obtained the lowest rates of the insect attack. The fruit and pit of the Fruta de Leite were bigger and heavier than the others, while the correlations among the predation rate and the other morphological variables of the fruit and pit were not significant. Amblycerus sp. and Carmenta sp. may be considered potential pests of pequi, with the risk of compromising the pequizeiro populations and the regional economics.
\end{abstract}

Keywords: Amblycerus sp. Carmenta sp. Cerrado. Morphological features. Pequi.

\section{OCORRÊNCIA DE INSETOS-PRAGA NOS FRUTOS DE Caryocar brasiliense (CARYOCARACEAE) NO NORTE DE MINAS GERAIS}

\begin{abstract}
RESUMO - Caryocar brasiliense Camb. conhecida comumente como pequizeiro, é uma espécie típica do Cerrado que representa relevante fonte de renda para as populações locais. No entanto, a ocorrência de insetospraga ocasiona sérias perdas na produção do pequizeiro, causando danos nos frutos e inviabilizando sua comercialização. Os objetivos foram identificar as espécies de insetos-praga dos frutos e putâmens do pequizeiro; comparar as características morfológicas de frutos e putâmens e os danos causados por insetos entre árvores matrizes e procedências e entender o efeito das características morfológicas sobre os danos causados pelos insetos. Foram avaliadas três procedências do norte de Minas Gerais, 12 matrizes por procedência e dez frutos por matriz. Os frutos foram abertos, verificados quanto ao ataque de insetos e determinadas as variáveis morfológicas. Em seguida, os frutos foram armazenados em copos cobertos com tela para a eclosão e posterior identificação dos insetos adultos. Tais insetos foram identificados como Carmenta sp. (Lepidoptera: Sesiidae) e Amblycerus sp.(Coleoptera: Chrysomelidae). Houve efeito significativo de matrizes e procedências para o percentual de frutos e putâmens atacados, onde a localidade Laje Velha obteve as menores taxas de ataque de insetos. Os frutos e putâmens de Fruta de Leite foram maiores e mais pesados que os demais, enquanto as correlações entre a taxa de predação e as variáveis morfológicas não foram significativas. Portanto, Amblycerus sp. e Carmenta sp. podem ser consideradas potenciais pragas do pequi, podendo comprometer as populações de pequizeiro e a economia regional.
\end{abstract}

Palavras-chave: Amblycerus sp. Carmenta sp. Cerrado. Características morfológicas. Pequi.

\footnotetext{
${ }^{*}$ Corresponding author

${ }^{1}$ Received for publication in $05 / 12 / 2020$; accepted in $06 / 15 / 2021$.

Paper extracted from the final work for the undergratuation of the first author

${ }^{2}$ Institute of Mathematics and Statistics, Universidade Federal da Bahia, Salvador, BA, Brazil; renanalvessantos@ufba.br - ORCID: 00000002-6255-3562.

${ }^{3}$ Teaching Department, Instituto Federal do Norte de Minas Gerais, Salinas, MG, Brazil; vinicius.orlandi@ifnmg.edu.br - ORCID: 00000003-4252-2942, tatianne.marques@ifnmg.edu.br - ORCID: 0000-0002-9397-0879.
} 


\section{INTRODUCTION}

The pequizeiro (Caryocar brasiliense Camb.) is a typical species of plant from the north region of Minas Gerais and it can be found especially in the formations of dystrophic and mesotrophic Cerradão, dense Cerrado, Cerrado, Cerrado restrict sense and sparse Cerrado (ALMEIDA et al., 1998). Its fruit, the pequi, shows uncountable beneficial effects to human health. Being rich in vitamins and essential oils, it acts in many systems in the human body, from the skeletal, muscular, endocrine to the immune system (TORRES et al, 2018). Its gastronomic appreciation and the possibility to be used in diverse traditional dishes make the pequi an expressive income for the local population in the harvest period (SILVA; TUBALDINI, 2013). The data found by the Brazilian Institute of Geography and Statistics (IBGE , 2019) shows that Brazil produced 27.183 tons of pequi fruit in 2019 and the north of Minas Gerais was responsible for $66,24 \%$ of this sum, being classified as the largest pequi producer in Brazil. Given the unquestionable importance of this species, for its environmental distribution as well for the community economics that manages it, Lopes et al. (2003) alerts that fruit and pit attacked by insects, especially on the pre-dispersion period, has threatened the species extractivism since the damage from the insect feed makes the fruit commercialization difficult and turn them inedible. In addition, this type of damage exerts an important influence on the population structure of this attacked plant, since it can cause high mortality of the seeds produced by the mother plant, decreasing then, the germination rate and the plant establishment and survival.

Among the various elements that can influence the action of pest insects, the fruit and pit morphological features need to be emphasized. Janzen (1970) claims that these variables are often related to the insect attack rate, since as higher are the availability and visibility of the resources to the insects as bigger are the chances of attack. The pequi shows considerable biometric variability among the mother plant established in the same population as well as among populations from different locations (LUZ et al., 2011; RAMOS; SOUZA, 2011; MOURA et al., 2013). This can be explained since phenotypical differences of fruit can be determined by local or regional environmental variation (BOTEZELLI; DAVIDE; MALAVASI, 2000; GUSMÃO; VIEIRA; FONSECA, 2006). Besides providing crucial information for the extraction practices, the knowledge on these biometric variables and its influence in the insect attack can assist in the selection of the mother plant with the desirable features and, through genetic improvement programs, increment the fruit and pit production.

Studies about the ecological relations of the insects with the pequizeiro are still incipient, which makes this theme an important line of research, since this plant species highly contributes on the socioeconomic development of countless Brazilian families, as well as on the ecological environment management in its biome. In this context, this paper has as objectives: (i) identifying the pest insects the pequi fruit and pit in the pre-dispersion period; (ii) to compare the fruit and pit morphological features and the damage caused by insects among mother plants and their original locations; (iii) correlate the fruit and pit morphological features with the insect damage.

\section{MATERIALS AND METHODS}

\section{Characterization of the region}

The pequi fruit were collected in March of 2014 in pequizeiro mother plants from three locations in the north of Minas Gerais (Figure 1). Those locations were: chapada region of Laje Velha (1607'33”S, 42 $\left.{ }^{\circ} 00^{\prime} 30^{\prime \prime} \mathrm{W}\right)$ and Riacho (1601'53”S, $\left.42^{\circ} 06^{\prime} 43^{\prime \prime} \mathrm{W}\right)$, located in the municipality of Salinas and in the rural area of the municipality of Fruta de Leite (1608'17'S, 42॰31'45'W).

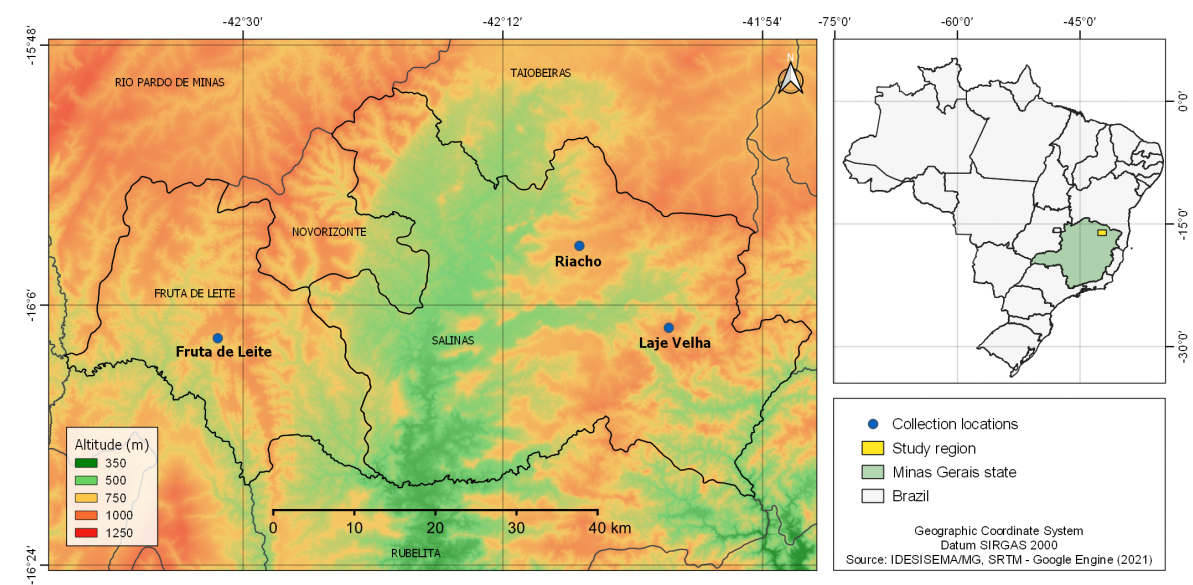

Figure 1. Location of the origin areas of the Caryocar brasiliense mother plants in the north of Minas Gerais. 
The pequizeiro population studied in Riacho is located in a Cerrado area on the margin of the road BR-251 leading to the state of Bahia, Brazil. The sampled trees are near eucalyptus stands and were found in a dense distribution, a characteristic also observed in other populations of $C$. brasiliense (BRUZINGA et al., 2014; FAVARE et al., 2018). The trees from Laje Velha and Fruta de Leite are localized in afforested pasture areas, formed by isolated remainder pequizeiros

\section{Experiment conduction}

A number of 12 mother plants were randomly selected in each area studied and 10 fruit were collected from them. They were in the final phase of physiologic maturation for each mother plant, totalling 360 fruit collected. Subsequently, the fruit were packaged in plastic bags and transported to
Laboratório de Ecologia Vegetal, at IFNMG Campus Salinas. There, they were peeled and the external mesocarps were removed for the evaluation of the presence or absence of the insects related to the mesocarps or pits. The fruit damages caused by insects were visually identified by the attack to the exocarp and extern mesocarp (peel) and the damages caused in the pit were identified by the attack to the intern mesocarp (pulp) and, in some cases, to the the endocarp and the embryo. After opening the fruit, the pits inside the fruit were counted. Also, the fruit and their pits were weighted with a weighing balance (scale $0.01 \mathrm{~g}$ ). In addition, a morphological measure was conducted on the pits, where the length and width of the pits were measured with a digital pachymeter $(0.1 \mathrm{~mm})$. After the measuring, the pits were stored in cups with polyethylene and sealed with a net $(0.5 \mathrm{~mm})$ for the insect hatching and identification (Figure 2).

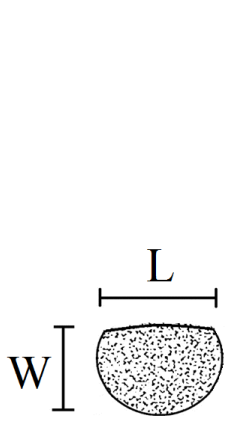

A

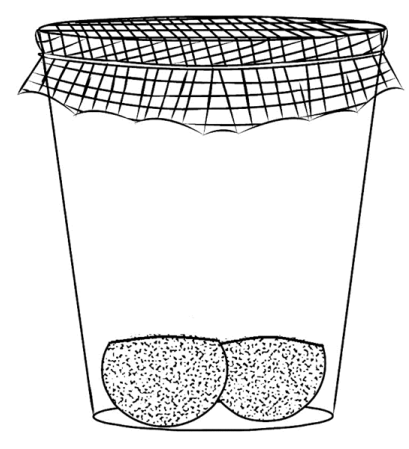

B

Figure 2. Measured length (L) and width (W) of the Caryocar brasiliense pits (A). A polyethylene cup sealed with a 0.5 mm-thick net to store pequi pits and facilitate the hatching of the eggs of insect pests (B).

From the beginning of the storing, weekly evaluations were made, quantifying the larvae and adult insect appearing from the pit interior. The adult emergence average time and the number of insect were analysed by fruit. The insects were identified by literature and taxonomists.

\section{Statistical analysis}

To evaluate the influence of the mother plant and its origin on the percentage of attacked fruit and pits, a chi-square test was conducted. The attack rate was estimated by the amount of fruit and pits that showed any damage caused by insects. The effect of the mother plant and their original location on the average weight of the fruit, on the average weight, length and width of the pits and on the number of pits by fruit were evaluated trough the analysis of variance of two factors followed by the Tukey test with $5 \%$ of probability.
After 120 days, which is the growth and development time of the predatory insects, all the pits were opened and their integrity was verified, then, the correlation between the number of attacked fruit and pit and their morphological features was calculated using the Pearson's coefficient (r). All the analyses were done on the Statistic software PAST (HAMMER; HARPER; RYAN, 2001).

\section{RESULTS AND DISCUSSION}

A number of 569 pits from 360 fruit was reached and two insect species that attacked the pequizeiro fruit and pits were identified. One specie belongs to the Lepidoptera order and Sesiidae family (Carmenta sp.) popularly known as "broca de pequizeiro" (Figure $3 \mathrm{~A}, \mathrm{~B}, \mathrm{C}$ and D), and another specie belongs to the Coleoptera order, Chrysomelidae family and sub-family Bruchinae 
(Amblycerus sp.) (Figure $4 \mathrm{~A}, \mathrm{~B}, \mathrm{C}$ and D). This is the first study that indicates the Amblycerus sp. as a predator of pequizeiro fruit and pits.

Regarding time of adult insect emergence, Carmenta sp. emerged in average of 25 days after the fruit collecting. The average time of Amblycerus sp. adult eclosion in this study was of 72 days after the fruit collecting and the units attacked did not present visible extern or intern symptoms in the fruit colleting or opening moments.

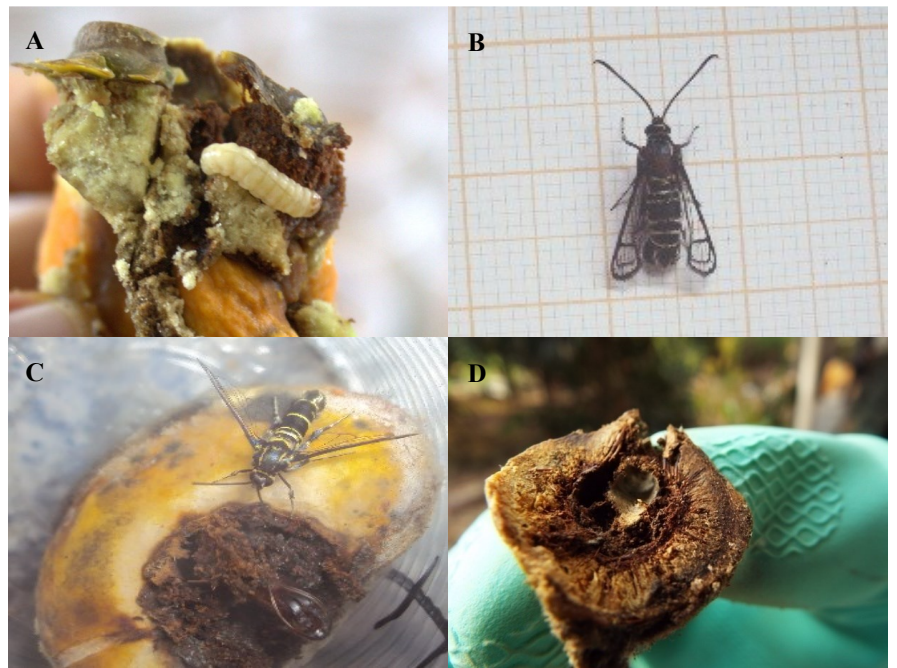

Figure 3. Carmenta sp. caterpillar (A); Carmenta sp. adult insect (B); Carmenta sp. moments after emerging from the cocoon (C); Characterization of the damage caused by Carmenta sp. to the Caryocar brasiliense pit (D).

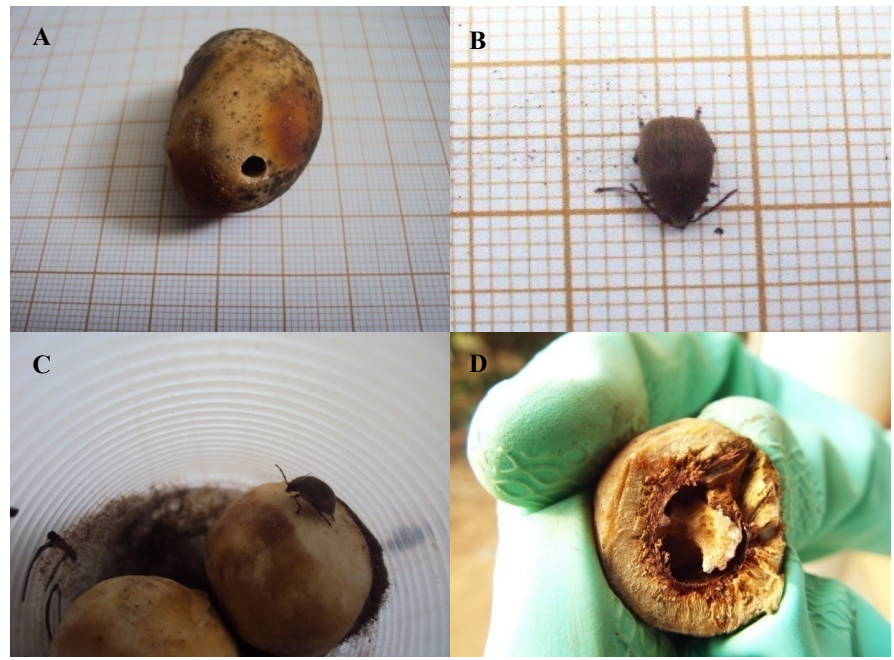

Figure 4. Circular hole caused by the Amblycerus sp. (A); Amblycerus sp. adult insect (B); Amblycerus sp. after emerging (C); Characterization of the Amblycerus sp. damage to the Caryocar brasiliense pit (D).

Carmenta sp. is being suggested in the literature as a potential insect pest of commercial cultivations of pequizeiros in the north of Minas Gerais due to its large occurrence in the region. The insect causes considerable damages in the pequi fruit and pits (LOPES et al., 2003; LEITE et al., 2012a,b) with the risk of compromising its production and propagation in natural environments.

Up to the moment, the species of the genus Carmenta that attacks the pequi were not identified which may be considered a new species (CARVALHO; CASTRO, 2016). Due to the negative effects of the Carmenta sp. attack on the $C$. brasiliense fruit, the taxonomic identification and the elaboration of population control measures of the insect are essencial and urgent for the preservation and management of pequizeiros in the region.

Eichlin and Passoa (1983) reported the existence of more than 200 neotropical species of the Carmenta genus distributed from Central America to Peru. Twenty-four species were described in Brazil (EICHLIN; KINNEE, 2002) and the majority of their host plants are unknown, with the exception of $C$. surinamensis that has a relationship with the seeds of some legumes, and $C$. theobromae and $C$. foraseminis which are known as major pests of cocoa 
(PUCHI, 2005; BENASSI et al., 2013).

Ferreira et al. (2009) studied the biodiversity of insects associated to $C$. brasiliense established in different origin of the Cerrado in Goiás. They determined the presence of the Carmenta sp. in nine from the sixteen populations evaluated. Carvalho and Castro (2016) identified Carmenta sp. in approximately $60 \%$ of the pequi fruit attacked in the Federal District region in Brazil. Thus, it can be inferred that $C$. brasiliense can be a preferred host species of Carmenta sp., since there is a synchrony between the peaks of the insect population with the period of the pequizeiro fructification (LEITE et al., $2012 \mathrm{~b}$ ). This can damage about $50 \%$ of the fruit (LOPES, et al., 2003; LUZ et al., 2011; CARVALHO; CASTRO, 2016) and, therefore, interfere in the pequizeiro population dynamics and in the income generation in the pequi commercialization.

According to Cubillos (2013), the Carmenta genus has a life cycle of 71 days in average. According to Rodrigues et al. (2015), the average maturation time of the pequizeiro fruit from the flower anthesis is 84 days and from the initial fruit formation is 77 days. Thus, according to the emergence time of the adult insect, it was estimated that the Carmenta sp. female egg posture on the fruit occurs when they are at the initial phase of development, with approximately 30 days after its formation. As reported by Lopes et al. (2003), this fact can be connected to the morphological features of the mature fruit that tend to make the caterpillar entry more difficult, since it has a hard endocarp.

The literature has few registers regarding the Amblycerus sp. and no reference showing its participation in the damage of pequizeiro was found. Due to the insect low occurrence in this study, there were not enough subsidies to correlate its pests' behaviour. Cavalcanti and Resende (2004), studying the damage from the insects feed in Spondias tuberosa seeds in the northeast semiarid, revealed the damage caused by $A$. dispar in the fruit could have caused the low seed germination and regeneration of the imbuzeiro plant in the region studied. For this species insect, the authors also observed that this Coleoptera larva penetrates the seed just after the mature fruit fall on the ground and it feeds itself from the embryo to the adult stage, when it perforates the seed causing a circular hole. A similar behaviour was observed in the pequizeiro pits analysed in our study.

Johnson, Romero and Raimúndez-Urrutia (2001) studied the attack of $A$. crassipunctatus on the seed of the family Humiriaceae. Besides stating a similar damage observed in this study, this author detected a life cycle of approximately 60 days from the egg posture to this species' adult stage. This development time of the insect was close to the estimated to Amblycerus sp. in this study, in which the emergence of the adult insect occurred around 72 days after the collection of the pequi fruit in the mother plant.

Counting more than 340 species described in the whole world, the Amblycerus genus is stated as the second biggest representative of the sub-family Bruchinae (KINGSOLVER, 1990). Futhermore, this insect group is considered the most generalist among the seed predators, owning a vast number of hosts that includes species from the botanic families of Fabaceae, Boraginaceae, Rhamnaceae, Euphorbiaceae, Sterculiaceae, Malpighiaceae, Anacardiaceae, Combretaceae, Malvaceae, Verbenaceae, Vitaceae e Humiriaceae (KINGSOLVER, 1990; JOHNSON; ROMERO; RAIMÚNDEZ-URRUTIA, 2001). With the possible inclusion of the Caryocaceae as a potential source for the Amblycerus feeding and reproducing habits, thirteen plant families having a relation with these insects are now established.

A hypothesis to the low percentage of the Amblycerus sp. occurrence is that this insect prefers the pequizeiro pit after its dispersion as found in the study conducted by Cavalcanti and Resende (2004). These authors reported a rate of more than $93 \%$ of attacks by this insect in imbuzeiro seeds collected on the ground, which was not observed in the seeds collected directly from the trees. In contrast, Farias et al. (2015) studying Buchenavia tomentosa in a Cerrado stricto sensu from the state of Mato Grosso found $A$. insuturatus larvae in fruit collected in the trees, indicating a pre-dispersion attack. In the same study, the authors also observed signals of emergence of the adult insects, characterized by the endosperm and embryo completely consumed. Taking into consideration the importance of the damage caused by the insect to the pequizeiro pits, more studies are necessary in order to elucidate its predatory behaviour and the determining factors in its distribution in the north of Minas Gerais.

From the total of fruit and pits collected, Carmenta sp. presented attack in 32 fruit (8.89\%) and 39 pits $(6.85 \%)$, with average occurrence of one insect by fruit, being observed two individuals in just one of the attacked fruit. While the Coleoptera Amblycerus sp. was responsible for the damage of two fruit $(0.56 \%)$ and two pits $(0.35 \%)$.

The studied pequizeiro trees showed a low fruit loss $(9.44 \%)$ and pits $(6.89 \%)$ due to insect feed in the pre-dispersion period. From the 36 mother plants analysed, 19 trees had at least one of their predated fruit and pits, with nine in Fruta de Leite, eight trees in Riacho and two in Laje Velha. The percentage of attacked fruit and pits revealed significant differences between mother plants and their original location $(p<0.05$; Table 1$)$, which demonstrates that the mother tree and environmental 
factors might be determinants to the insect attack in the pits, showing the necessity to consider these aspects on the genetic improvement programs regarding their influence in the pequi production.
The trees from Laje Velha showed lower values of insect damage on fruit and pits, while the locations Riacho and Fruta de Leite presented were statistically similar (Table 2).

Table 1. Chi-square values and p-value in the comparison of percentage of attacked fruit and pits among Caryocar brasiliense mother plants and their original locations in the north of Minas Gerais.

\begin{tabular}{ccccc}
\hline & \multicolumn{2}{c}{ Attacked fruit (\%) } & \multicolumn{2}{c}{ Attacked pits (\%) } \\
\hline$\chi^{2}$ & $\mathrm{p}$ & $\chi^{2}$ & $\mathrm{p}$ \\
\hline Mother plants & 51.317 & 0.0370 & 67.550 & 0.0008 \\
Original location & 10.888 & 0.0050 & 12.854 & 0.0016 \\
\hline
\end{tabular}

Table 2. Number of Caryocar brasiliense fruit and pits attacked by insects in three locations in the north of Minas Gerais.

\begin{tabular}{ccccccc}
\hline Locations & AF & NAF & AF(\%) & AP & NAP & PA(\%) \\
\hline Riacho & 17 & 103 & $14.17 \mathrm{a}$ & 22 & 174 & $11.22 \mathrm{a}$ \\
Laje Velha & 3 & 117 & $2.50 \mathrm{~b}$ & 3 & 172 & $1.71 \mathrm{~b}$ \\
Fruta de Leite & 14 & 106 & $11.67 \mathrm{a}$ & 16 & 182 & $8.08 \mathrm{a}$ \\
\hline Total/Average* & 34 & 326 & $9.44^{*}$ & 41 & 528 & $6.89^{*}$ \\
\hline
\end{tabular}

$\mathrm{AF}=$ attacked fruit; NAF = non attacked fruit; $\mathrm{AF}(\%)=$ percentage of attacked fruit; $\mathrm{AP}=$ attacked pits; NAP $=$ non attacked pits; $\mathrm{PA}(\%)=$ percentage of attacked pits. Averages followed by the same letter in each column do not differ statistically by the chi-square test.

A low percentage of damage in pequi fruit caused by insects was found in this study, however, other authors noticed more elevated indices to this type of interspecific interaction. Leite et al. (2012b), found perforations occasioned by Carmenta sp. in $24,31 \%$ of the pequi fruit collected in the predispersion phase in a Cerrado strictu sensu of the Montes Claros, north of Minas Gerais. It is also noted the fact that the pequizeiro pits show physiological and tegumental dormancy, staying long periods in contact with the soil after its dispersion, what makes the damage caused by insects increase considerably. In a study conducted by Lopes et al. (2003), the authors detected the presence of Carmenta sp. in approximately $50 \%$ of the fruit collected on the soil of the south and north of Minas Gerais. Both literature reporters and observations made in this study show that the two insects (Carmenta sp. and Amblycerus sp.) damage the pequi pit embryo, probably preventing the seed to germinate, increasing the difficulty of the plant production and regeneration in its natural environment. In addition, the fruit and pits destruction is highly harmful to the local populations that rely on the extractivism, since the pequizeiro is widely exploited in the Brazilian Cerrado, showing significant contribution in those communities' income (LUZ et al., 2011; SILVA; TUBALDINI, 2013; BORGES et al. 2020).
Regarding the morphological analyses, the difference among the phenotypic characters was more significant in the locations studied, showing that the average of the characters suffered influence of the environment that the mother plants are located (Table 3). It was observed that the weight of the fruit and the width, length and weight of pits varied among the original locations and Fruta de Leite displayed the highest averages of all the parameters evaluated. In the evaluation among the mother plants, the difference was observed only for the average weight of the fruit.

The correlations conducted between the number of attacked fruit and pits with their morphological features did not show significant values of the Pearson's coefficient, indicating that the analysed biometric characteristics did not influenced the insect damage of pequizeiro fruit and pits (Table 4).

The results obtained in this present study substantiate the data of different authors that indicate a great variability on the fruit and pits morphological features among mother trees of native species. Probably it is due to the mother plant and population effects, since the location studied has intrinsic environmental variations (BOTEZELLI; DAVIDE; MALAVASI, 2000; SANTOS et al., 2009; LUZ et al., 2011; NASCIMENTO; CARDOSO; COCOZZA, 2014). Even though the environmental features were not measured in this study, it was 
possible to verify that the most distant pequizeiro population, as in Fruta de Leite location, presented the fruit and pits morphological characteristics with the highest averages and differences from other locations. This can be a result of the climate and soil conditions which in association can influence the fruit biometric features (LUZ et al., 2011) and contribute to resistance and susceptibility to the insect damage.

Table 3. Average values of the morfological features of Caryocar brasiliense fruit and pits from three locations in the north of Minas Gerais.

\begin{tabular}{cccccc}
\hline Locations & W.F. $(\mathrm{g})$ & L.P. $(\mathrm{mm})$ & W.D.P. $(\mathrm{mm})$ & W.P. $(\mathrm{g})$ & N.P./F. \\
\hline Fruta de Leite & $182.9 \mathrm{a}$ & $42.56 \mathrm{a}$ & $32.24 \mathrm{a}$ & $25.13 \mathrm{a}$ & $1.65 \mathrm{a}$ \\
Laje Velha & $141.3 \mathrm{~b}$ & $37.50 \mathrm{~b}$ & $28.82 \mathrm{~b}$ & $18.82 \mathrm{~b}$ & $1.46 \mathrm{a}$ \\
Riacho & $131.9 \mathrm{~b}$ & $36.58 \mathrm{~b}$ & $28.18 \mathrm{~b}$ & $15.40 \mathrm{~b}$ & $1.62 \mathrm{a}$ \\
\hline Average & 152.0 & 38.88 & 29.75 & 19.78 & 1.54 \\
Standard deviation & 27.16 & 3.22 & 2.18 & 4.94 & 0.11 \\
CV (\%) & 17.86 & 8.28 & 7.34 & 24.95 & 7.35 \\
\hline p - Origins & 0.0018 & 0.0000 & 0.0001 & 0.0000 & 0.5558 \\
p - Mother plants & 0.0196 & 0.4103 & 0.2372 & 0.3078 & 0.8647 \\
\hline
\end{tabular}

W.F. $=$ Weight of the fruit; L.P. = Lenght of the pits; W.D.P. = Width of the pits; W.P. = Weight of the pits; N.P./F. = Number of pits per fruit; $C V(\%)=$ coeficiente of variation; $p$ - Origins $=p$ value in the comparison among origins in the ANOVA; $\mathrm{p}-$ Mother plants $=\mathrm{p}$ value in the comparison among mother plants in the ANOVA. Averages followed by a same letter in the column do not differ statistically by the Tukey test $(5 \%)$.

Table 4. Correlation between the rates of insects damage of Caryocar brasiliense fruit and pit and the morphological features measured.

\begin{tabular}{lll}
\hline & \multicolumn{2}{c}{ Pearson's correlation coefficient $(\mathrm{r})$} \\
\cline { 2 - 3 } Variable & Fruit & Pit \\
\hline Weight of the fruit & $\mathrm{r}=0.0704^{\mathrm{ns}}$ & $\mathrm{r}=0.0682^{\mathrm{ns}}$ \\
Weight of the pit & $\mathrm{r}=0.0759^{\mathrm{ns}}$ & $\mathrm{r}=0.0364^{\mathrm{ns}}$ \\
Length of the pit & $\mathrm{r}=0.1170^{\mathrm{ns}}$ & $\mathrm{r}=0.0706^{\mathrm{ns}}$ \\
Width of the pit & $\mathrm{r}=0.0970^{\mathrm{ns}}$ & $\mathrm{r}=0.0693^{\mathrm{ns}}$ \\
Number (average) of pit per fruit & $\mathrm{r}=0.1994^{\mathrm{ns}}$ & $\mathrm{r}=0.2973^{\mathrm{ns}}$ \\
\hline
\end{tabular}

$\mathrm{ns}=$ not significant $(p>0.05)$.

The absence of relation between the number of attacked fruit and pits and their morphological features may be associated to the fact that the Carmenta female adults lay their eggs on pequi fruit still in formation, which may justify the low correlation found. Despite of not observing the insect preference in feeding on more or less vigorous fruit and pit, Fruta de Leite location, responsible for the highest averages on the morphological variables, was also a highlighted area for the number of fruit attacked, along with Riacho location. Luz et al. (2011) verified an opposite dynamic, where the lowest number of pits attacked by insects was found in the same area that presented the most vigorous fruit. As a result, it is possible that other factors, beyond those measured in this study, are more directly connected to the pequi attack rate, showing that more studies are required on the subject.

\section{CONCLUSION}

Carmenta sp. and Amblycerus sp. were the insect species responsible for the damage caused to the pequizeiro fruit and pits in the pre-dispersion period in the region studied in the north of Minas Gerais. They also cause losses to the integrity and quality of the fruit that can compromise its production and commercialization. There were differences among the mother plants and the 
locations regarding the percentage of attacked fruit and pits, where Laje Velha obtained the lowest rates of insect attack. The pequi fruit and pits of Fruta de Leite region were bigger and heavier than the others, while the correlations among the insect damage and the morphological variables of fruit and pits were not significant.

\section{ACKNOWLEDGMENT}

The authors would like to thank IFNMG for the research support and the scientific initiation scholarship provided to R.A.S.

\section{REFERENCES}

ALMEIDA, S. P. et al. Cerrado: espécies vegetais úteis. 1. ed. Planaltina, DF: Embrapa Cerrados, $1998.464 \mathrm{p}$.

BENASSI, V. L. R. M. et al. Carmenta foraseminis (Lepidoptera: Sesiidae), nova broca de frutos de cacau no Brasil. Revista de Agricultura, 88: 70-75, 2013.

BORGES, M. L. et al. Ocorrência de espécies com potencial de exploração econômica como o pequizeiro (Caryocar brasiliense) e o buritizeiro (Mauritia flexuosa) no norte de Minas Gerais Brasil. RA'EGA, 8: 162-178, 2020.

BOTEZELLI, L.; DAVIDE, A. C.; MALAVASI, M. M. Características dos frutos e sementes de quatro procedências de Dipteryx alata VOGEL (baru). Cerne, 6: 9-18, 2000.

BRUZINGA, J. S. et al. Distribuição espacial de individuos adultos de pequi. Scientia Forestalis, 41: 249-256, 2014.

CARVAlHO, R. L. S.; CAStro, M. T. Ataque de Carmenta sp. (Lepidoptera: Sesiidae) em pequizeiros no Distrito Federal, Brasil. Revista Científica Eletrônica de Engenharia Florestal, 28: 14-22, 2016.

CAVAlCANTI, N.; RESENDE, G. M. Danos provocados por insetos a sementes do imbuzeiro no semi-árido do nordeste brasileiro. Caatinga, 17: 9397, 2004.

CUBillos, G. Manual del perfurador de la mazorca del cacao Carmenta foraseminis (Busck) Eichlin. Medellin, Colombia: Compañía Nacional de chocolates S.A.S., 2013. 32 p.
EICHLIN, T. D.; KINNEE, S. A. Brazilian Sesiidae in the collection of the Universität des Saarlandes, Saarbrücken, Germany (Lepidoptera). Zootaxa, 108: $1-15,2002$.

EICHLIN, T. D.; PASSOA, S. A new clearwing moth (Sesiidae) from Central America: a stem borer in Mimosa pigra. Journal of the Lepidopterists Society, 37: 193-206, 1983.

FARIAS, J. et al. Seed dispersal and predation of Buchenavia tomentosa Eichler (Combretaceae) in a Cerrado sensu stricto, midwest Brazil. Brazilian Journal of Biology, 75: 88-96, 2015.

FERREIRA, G. A. et al. Biodiversidade de insetos em Pequizeiro (Caryocar brasiliense, Camb.) no cerrado do Estado de Goiás, Brasil. Agrociência, 13: 14-23, 2009.

FAVARE, H. G. et al. Produção de forragem e distribuição espacial de árvores de pequi em sistema silvipastoril. Nativa, 6: 714-721, 2018.

GUSMÃO, E.; VIEIRA, F. A.; FONSECA, E. M. Biometria de frutos e endocarpos de murici (Byrsonima verbascifolia Rich. Ex. A. Juss). Cerne, 12:84-91, 2006.

HAMMER, Ø.; HARPER, D. A. T.; RYAN, P. D. PAST: Paleontological statistics software package for education and data analysis. Palaeontologia Electronica, 4: 4-9, 2001.

IBGE - Instituto Brasileiro de Geografia e Estatística. 2019. Produção da Extração Vegetal e da Silvicultura. Disponível em: https:// biblioteca.ibge.gov.br/visualizacao/periodicos/74/ pevs_2019_v34_informativo.pdf. Acesso em: 22 Jun. 2021.

JANZEN, D. H. Herbivores and the number of tree species in tropical forest. American Naturalist, 104: $501-528,1970$

JOHNSON, C. D.; ROMERO, J.; RAIMÚNDEZURRUTIA, E. Ecology of Amblycerus crassipunctatus Ribeiro-Costa (Coleoptera: Bruchidae) in seeds of humiriaceae, a new host family for bruchids, with an ecological comparision to other species of Amblycerus. The Coleopterists Bulletin, 55: 37-48, 2001.

KINGSOLVER, J. M. Checklist of Chilean Bruchidae with new synonymies and new combinations (Coleoptera). Revista Chilena de Entomología, 18: 49-52, 1990. 
LEITE, G. L. D. et al. The mortality of Caryocar brasiliense in northern Minas Gerais State, Brazil. Acta Scientiarum Agronomy, 34: 131-137, 2012a.

LEITE, G. L. D. et al. Seasonal damage caused by herbivorous insects on Caryocar brasiliense (Caryocaraceae) trees in the Brazilian savanna. Revista Colombiana de Entomologia, 38: 35-40, 2012b.

LOPES, P. S. N. et al. Caracterização do ataque da broca dos frutos do pequizeiro. Revista Brasileira de Fruticultura, 25: 540-543, 2003.

LUZ, G. R. et al. Caracterização física de frutos e putâmens e taxa de ataque por Carmenta sp. a pequizeiros (Caryocar brasiliense CAMB.) no norte de Minas Gerais. Revista Brasileira de Fruticultura, 33: 746-756, 2011.

MOURA, N. F. et al. Variabilidade entre procedências e progênies de Pequizero (Caryocar brasiliense Camb.). Scientia Forestalis, 41: 103$112,2013$.

NASCIMENTO, R. S. M.; CARDOSO, J. A.; COCOZZA, F. D. M. Caracterização física e físicoquímica de frutos de mangabeira (Hancornia speciosa Gomes) no oeste da Bahia. Revista Brasileira de Engenharia Agrícola e Ambiental, 18: 856-860, 2014.

PUCHI, N. D. Caracterización morfológica de los Sesiidae (Insecta: Lepidoptera) perforadores del fruto Del cacao (Theobroma cacao L.), presentes en la región costera del estado Aragua, Venezuela. Entomotropica, 20: 97-111, 2005.

RAMOS, K. M. C.; SOUZA, V. A. B. Características físicas e químico-nutricionais de frutos de pequizeiro (Caryocar coriaceum wittm.) em populações naturais da região meio-norte do Brasil. Revista Brasileira de Fruticultura, 33: 500508, 2011.

RODRIGUES, L. J. et al. Crescimento e maturação do pequi do cerrado brasileiro. Food Science and Technology, 35: 11-17, 2015.

SANTOS, F. S. et al. Biometria e qualidade fisiológica de sementes de diferentes matrizes de Tabebuia chrysotricha (Mart. Ex A. DC.) Standl. Scientia Forestalis, 37: 163-173, 2009.

SILVA, M. N. S.; TUBALDINI, M. A. S. O ouro do cerrado: a dinâmica do extrativismo do pequi no norte de Minas Gerais. Revista Eletrônica Geoaraguaia, 3: 293-317, 2013.
TORRES, L. R. O. et al. Bioactive compounds and functional potential of pequi (Caryocar spp.), a native Brazilian fruit: a review. Grasas y Aceites, 69: e257, 2018.

This work is licensed under a Creative Commons Attribution-CC-BY https://creativecommons.org/licenses/by/4.0 